\title{
Management of sunflower powdery mildew caused by Erysiphe cichoracearum DC. with botanicals and natural products
}

\author{
B.M. DINESH, SHRIPAD KULKARNI*, S.I. HARLAPUR, V.I. BENAGI AND C.P. MALLAPUR
}

Department of Plant pathology, College of Agriculture, University of Agricultural Sciences, DHARWAD (KARNATAKA) INDIA

\section{ARITCLE INFO}

Received : 20.06 .2015

Revised : 12.08 .2015

Accepted : 27.08 .2015

KEY WORDS :

Sunflower powdery mildew, Erysiphe circhoracearum DC., Lantana camara (leaf extract)

*Corresponding author:

Email: shripadkulkarni@ rocketmail.com

\begin{abstract}
Sunflower is reported to suffer heavy losses because of fungal, viral and bacterial diseases and one of the prominent diseases among them is powdery mildew caused by E. cichoracearum. Recently Powdery mildew is most important limiting factors for production of sunflower in Karnataka. Management of powdery mildew in sunflower was studied in both in vitro and in vivo conditions. Azadirachtin, NSKE, Turmeric (leaf extract), Lantana camara (leaf extract) and Ipomoea carnea (leaf extract) were effective in inhibiting spore germination of pathogen both under in vitro condition at 5 per cent concentration. Similar trend was observed in field condition also with Azadirachtin and NSKE at 5 per cent concentration with least disease incidence of 25.78 and 27.56 per cent disease index, respectively in contrast to 83.33 per cent disease index in control.

How to view point the article : Dinesh, B.M., Kulkarni, Shripad, Harlapur, S.I., Benagi, V.I. and Mallapur, C.P. (2015). Management of sunflower powdery mildew caused by Erysiphe cichoracearum DC. with botanicals and natural products. Internat. J. Plant Protec., 8(2) : 295298.
\end{abstract}

